\title{
Polysèmes
}

Revue d'études intertextuelles et intermédiales

11 | 2011

Cadres

\section{Framing National, Literary, and Gender Identities in Early American Epistolary Fiction}

\section{Christian Quendler}

\section{(2) OpenEdition}

\section{Journals}

\section{Electronic version}

URL: http://journals.openedition.org/polysemes/642

DOI: $10.4000 /$ polysemes. 642

ISSN: 2496-4212

\section{Publisher}

SAIT

\section{Printed version}

Date of publication: 1 January 2011

Number of pages: 87-113

ISSN: 0999-4203

\section{Electronic reference}

Christian Quendler, « Framing National, Literary, and Gender Identities in Early American Epistolary

Fiction », Polysèmes [Online], 11 | 2011, Online since 01 March 2015, connection on 20 April 2019.

URL : http://journals.openedition.org/polysemes/642 ; DOI : 10.4000/polysemes.642

This text was automatically generated on 20 April 2019.

Polysèmes 


\title{
Framing National, Literary, and Gender Identities in Early American Epistolary Fiction
}

\author{
Christian Quendler
}

1 Much of the historical appeal of early epistolary fiction arises from the contradictions involved in the fictional scheme of turning private documents into a public book. This highly transgressive feature turns epistolary novels into heuristic forms where cultural tensions, the limits of the private and the public sphere as well as the limits of the body can be gauged. As a crucial mediating interface, the construction of the communicative situation in early American fiction provides a rewarding field to study these frictions. This essay sets out to explore how early American epistolary novels frame and reframe communicative scenarios established in eighteenth-century European fiction. I suggest that one should read deviances from received communicative patterns as a response to the cultural double imperative in the Early Republic: the construction of a national body of literary fiction, while probing the experiential, subversive, and transgressive dimensions of fiction that pose a threat to strategies of social control. More specifically, I want to outline a repertoire of national, literary, and gendered framing strategies in the communicative design of epistolary novels that contributed to what Daniel Ward Howe in Making the American Self has studied as the cultural preoccupation with "the proper construction of the self" (1). ${ }^{1}$

2 My reading of early American novels is based on insights in frame theory as developed in sociology, anthropology, and the interdisciplinary research of cognitive sciences. Following Gregory Bateson's and Erving Goffman's seminal contributions to frame theory, I define mental frames as metacommunicative concepts by which we navigate through our symbolic universe. Frames organize familiar patterns of knowledge and establish general points of reference that guide comprehension. I use the term framing in contradistinction to the mental concept "frame" to designate the signaling of frames. As Gregory Bateson points out in his pioneering essay on frame theory, the distinction between frame and framing is essential. Framings externalize characteristics of our 
mental frames, because we find it easier to navigate in a universe in which some aspects of our mental maps are physically marked. ${ }^{2}$ According to this distinction, the physical frame of a picture is a framing that tells us to apply an aesthetic frame of interpretation when processing the representation depicted on the canvas. This relation between framings and frames makes frame theory particularly useful for historical analysis. I would like to put Bateson's observation in a historical perspective in order to illustrate how studying changes in the organization of novelistic framings can contribute to a historical theory of the novel.

3 In Seuils, which can be regarded as an important monograph in literary framing theory, Gerard Genette underscores the importance of paratexts for studying a pragmatics of fiction. As Genette argues, thanks to their liminal position at the threshold of fiction, paratexts afford us with privileged objects for studying the transactions between author, reader, and cultural context. ${ }^{3}$ I want to extend Genette's scope in two regards. Firstly, in contrast to his synchronic and typological approach, I see paratexts from a historical perspective and in a specific cultural and generic context. Secondly, I will step over the paratextual threshold into the beginning of the main text. Thus, in addition to paratextual framings I will consider intratextual framings, by which I mean metatextual comments that occur at the beginning of the main text. ${ }^{4}$ An analysis of framings in the peripheral structure of novels can bring out in more detail the tensions and social frictions that characterize the beginnings of American fiction. To illustrate this I want to show how framings negotiate the social, cultural, and aesthetic frames that shaped the beginnings of the American novel. I will pay special attention to discrepancies between framings and the framed text, and I suggest reading these inconsistencies and contradictions between the framing and the framed as indicative of a discursive anxiety to control the literary imagination in early American fiction.

\section{Epistolary Fiction and the Boundaries of the Public and the Private}

As Howe points out,

there was a growing interest in the shaping of individual and collective identities, not through the kind of institutional engineering that had concerned the framers of the Constitution, but through such cultural means as manners, literature, religion, education, and voluntary benevolence. (109)

5 The double structure of the novel frame as a cultural practice of communication and a vehicle of private intuition served as an ideal, albeit precarious medium for this educational and experiential purpose. On the one hand the novel represents a practice of social communication embedded in a public exchange of cultural self-expression. On the other hand, the imaginary content of fiction is processed in highly individual ways. The way we picture certain aspects of a story is private, idiosyncratic, and largely incommunicable. ${ }^{5}$ Historically, this constitutive duplicity of literary fiction as public discourse of private interaction assumed a crucial function in negotiating the communal and the private. Novels provided a popular format to respond to the official authorities of public life. They were invoked as instructional devices, as complements to history and science. And given the growing demand for entertainment and reading matter about American experiences, novels served as a means of cultural self-expression that contributed to the production of a common stock of national culture and literature. 
6 Yet, in the republican mentality, which highly valorized the communal, the novel's focus on individuality, the imaginative license it gave to readers as well as the retreat from sociality that accompanied (especially silent) novel reading were considered pernicious and subversive features. In Reading Becomes a Necessity of Life, William J. Gilmore remarks that detractors of the novel often argued that the novel encouraged "a new private reading style and so fostered alternatives to the wisdom of the ages, the basic value system underpinning reading instruction" (39). I would like to suggest that in the historical and cultural climate of late-eighteenth century America this subversive quality was subjected to framing strategies that shaped communicative scenarios of epistolary narratives in a way which kept female embodiment and narrative enactment carefully embedded in the realm of social control.

7 The paradoxical fusion of the public and the private in the epistolary format can be studied as a signpost that negotiates the limits of the public sphere. As Elizabeth Heckendorn Cook argues:

Consisting of personal letters, very often those of women, that are brought into the public sphere of print culture, epistolary narratives are necessarily concerned with determining the boundaries of public and private-and with questions of gender and corporealization that are inextricably involved in this definition. (12)

8 As the private core of the familial institution, the education of women assumed a central role in the republican educational model, which was heavily based on the analogy of the individual character and the construction of commonwealth. ${ }^{6}$ In this sense, the literary staging of the tension between the private and the public sphere in epistolary fiction contributed to the popularity of the genre in the US at a time when in Europe the epistolary novel was already in demise. The popularity was, however, only short-lived. Epistolary novels virtually disappeared after the first decade of the nineteenth century. Yet, the brief fad for epistolary fiction at the historical beginning of the American novel, the development of its form, and its supplanting by other forms of narrative transmission offer rewarding insights into the positioning of the female body and the alignment of narrative fiction with the public discourse of constructing a national literary body.

9 The rise of the eighteenth-century epistolary novel is closely related to the introspective aesthetics of sensibility, which found a congenial form in the epistolary mode. Imitating private communication, the epistolary form presents an effective means of putting into practice the idea of sensibility, which can be generally defined as introspected and reflected feelings. As a refined feeling the sentimental was thought to forge a link between feeling and reason and thereby substantiate the moral sense. ${ }^{7}$ The letter gives individual characters the opportunity to express their immediate feelings, reflect upon them, and thereby communicate them to friends. By presenting characters in the midst of moral conflicts and having them reflect and comment on these, the epistolary form could exact from fiction demands for verisimilitude and a moral code of conduct at the same time.

10 Notwithstanding the variety of epistolary forms of fiction, I would like to address three general features of epistolary fiction that played a key role in framing early American novels: ${ }^{8}(1)$ the documentary character, (2) the author's posture as editor, and (3) the intertextual hybridity facilitated by the letter form.

11 First of all, the documentary character of epistolary narratives and the simulation of written communication provided effective means for claims of authenticity and justified morally doubtful aspects with reference to its seeming factuality. The epistolary format 
thereby contributed a pervasive paratextual framing strategy of presenting early American fiction. In fact, more than a fifth of the novels published between 1790 and 1820 allege the truthfulness of the work on the title page, either by explicit mention or, implicitly, through the accumulation of facts. ${ }^{9}$ Typical phrases that subtitle these works are "A Tale of Truth", "Founded on Facts" or "Based on Recent Incidents". Virtually all novels of the early period made efforts to authenticate the fiction in prefaces, advertisements, or dedicatory epistles. In cases where the novelty (its recentness or originality) is stressed, claims of truthfulness were sometimes combined with sensational and topical lures. ${ }^{10}$

Secondly, editing a series of seemingly non-fabricated letters was a good way to evade the morally precarious issue of the author's indulging in acts of fictionalization. The belittling of an author's original contribution to creating a fictional world by referring to him or her simply as editor had become a rhetorical device that can also be found in nonepistolary works. Female Quixotism (1801) by Tabitha Tenney, who referred to herself as the "compiler" (3) of the story, is a case in point of an early parody of this narratorial self-denial in non-epistolary fiction. Nathaniel Hawthorne's The Scarlet Letter (1850) represents a more elaborate and well-known example, where the author self-ironically presents himself as the "editor, or very little more"11 (3).

Thirdly, the form of the letter could not only be aligned with other more respectable nonfictional genres, it also made it possible to easily amalgamate fictional and non-fictional elements as well as narrative and non-narrative passages. When examining the communicative framework novels as narrative fictions, one can observe two global strategies of presenting fictional narratives in a culturally favorable fashion. One common way was to mingle the fiction with other established discursive practices by embedding it in larger frames that emulated more respectable and often also nonfictional genres. ${ }^{12}$ Another popular strategy of ennobling novelistic fiction was to exempt the work in question from criticism by endowing it with moral and educational imperatives or by contrasting the novel as a potentially respectable genre to other romance fiction. The first framing strategy aligns the fictional narrative with other cultural narratives and discursive practices. The second, in drawing on the distinction between novel and romance, operates within the more specific generic frame of novelistic fiction.

\section{Epistolary Narratives as Public Letters}

The first strategy is particularly evident in works that assemble fictional texts along with non-fictional ones. Significantly, the narrative fictions are not only kept separate from non-fictional passages but are often subordinated to them. Following the tradition of miscellaneous publications such as almanacs and didactic literature, the anonymously published The Vain Cottager (1807), prefixes its main narrative attraction the "History of Lucy Franklin" with "a few hints to young women in humble life, respecting decency and propriety of dress" (qtd. from title page). A particularly graphic instance of the subservient role early American fiction assumed can be obtained from the presentational design of the works of Enos Hitchcock, a Federalist and pastor in Rhode Island (see figure 1). The title of Memoirs of the Bloomsgrove Family (1790), which is sometimes considered the second American novel, invokes the biographical genre of the memoir. (Similarly, his second work is subtitled The History of M. Charles Worthy). In addition, the memoir is 
presented in epistolary form significantly addressed to "a respectable citizen of Philadelphia". The attributes given to the addressee (and the eponymous hero of The Farmer's Friend) assume a modeling character for the intended literary exchange with the reader. The respectability of the addressee and the fact that he lives in Philadelphia are cues that underscore the relevance the book has for American readers. Likewise, the allegorical name of M. Worthy and his story of virtuous success (which on the title page is summarized as the story of "a poor Orphan, [who] rose through various Scenes of Distress and Misfortune, to Wealth and Eminence, by INDUSTRY, ECONOMY and GOOD CONDUCT") provide, on the level of story, an exemplary model of behavior.

Figure 1: Title pages of Enos Hitchcock, Memoirs of the Bloomsgrove Family (1790) and The Farmer's Friend (1793)

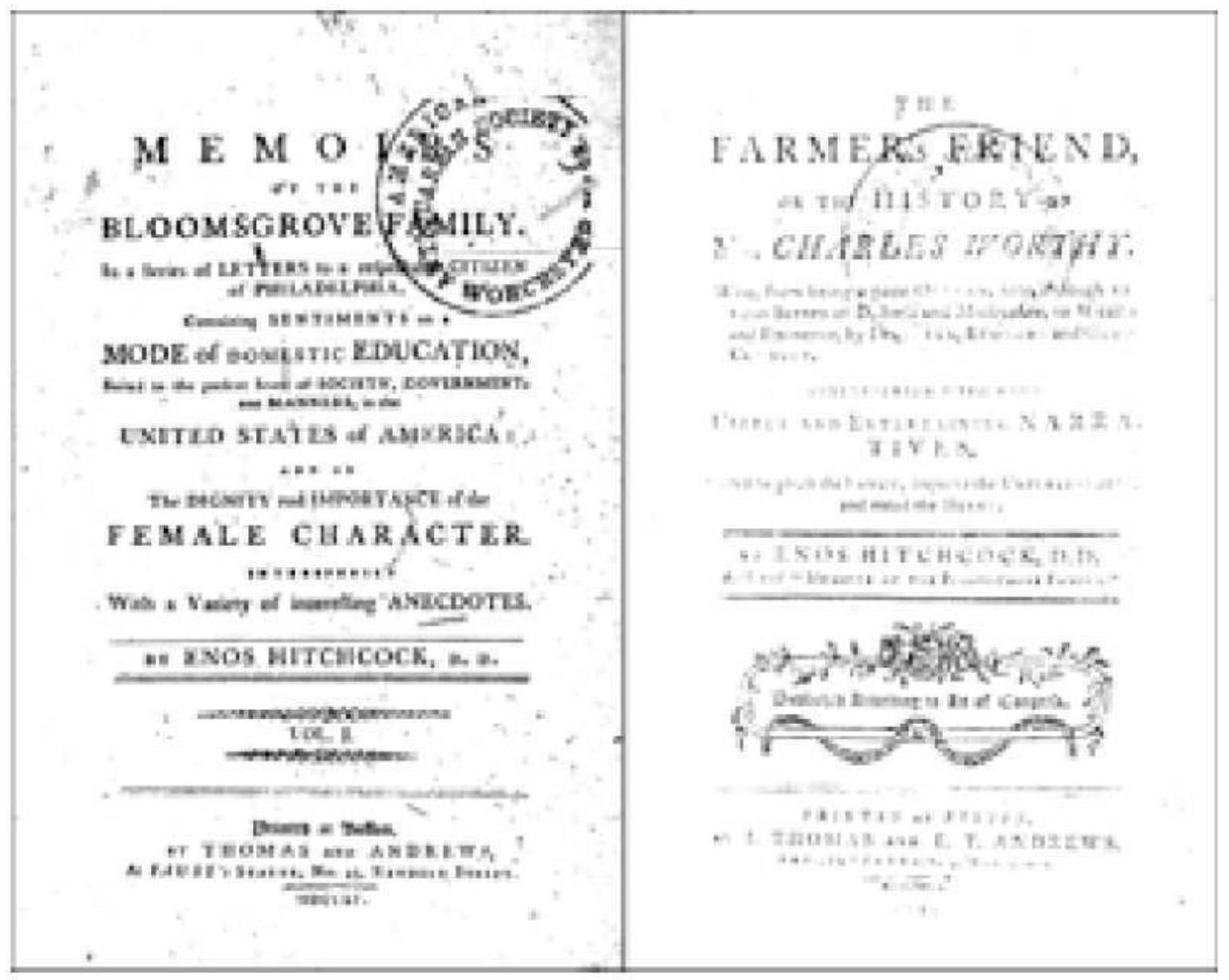

The main title words of The Farmer's Friend extend this exemplary function to the communicative dimension. The title supports a metonymical interpretation that conceives of the book as a beneficial social companion for industrious farmers, who represent the target audience of the novel, as shown by the dedicatory epistle "To All Farmers, Through The United States". ${ }^{13}$

The numerous framings that mark the subservient function of the narratives can be read as a response to the agrarian mentality, for which reading fiction required particular legitimizing efforts. On an individual level this subservient function aims at improving the faculties of the imagination. The fiction is "suited to please the FANCY, improve UNDERSTANDING, and mend the HEART" (see title page of The Farmer's Friend); on a social level the potential educational merit is "Suited to the present State of SOCIETY, GOVERNMENT, and MANNERS, in the UNITED STATES OF AMERICA" (see title page of Memoirs of the Bloomsgrove Family). 
17 While the documentary character of the epistolary form and the intertextual embedding of the fiction in the social practice of public discourse were welcome features to add prestige to the early American novels, the editorial substitution of the narrator as agent of narrative control represented a rather precarious literary device. The very act of disappearing by means of a fictive editorial scheme required some caution so as not to divert the attention too much from the moral content of the letters to the playful act of their fictional arrangement. Or put more drastically, framing literary fiction by means of the literary device of a fictive editor carried the risk of fictionalizing the reading process altogether and detaching the reader from the social world of sentiments.

Thus it is perhaps not surprising that among early editorial framing strategies in the epistolary novel the editorial pattern, in which the author aligns with the writer of letters, was not uncommon. In epistolary works like Hitchcock's Memoirs of the Bloomsgrove Family (1790) or Jeremy Belknap's humorous allegory The Foresters: An American Tale (1792) the author of the work and the sender of the letter appear to be nominally the same. Although the epistolary design of the book recalls a specific communicative situation, it is not exploited dramatically. In fact, in both cases the editorial scheme receives only a brief mention on the title page. In Memoirs of the Bloomsgrove Family the reductive design of the communicative situation is in line with the overly non-fictional, educational objective of the work, in which the exemplary character of the memoirs and other anecdotes (such as the "Anecdote of a French Lady" or "An Ancient Story") perform only a subordinated illustrating function.

19 Similarly, Belknap's The Foresters remains functionally indebted to the older type of the epistolary travelogue. Hitchcock and Belknap thereby shift the emphasis to the extrafictional and arguably the public dimension-an effect that is further enhanced by not identifying the addressee. In a sense the close alignment between the author and sender mirrors the open identification between reader and recipient. Although these works are framed as promise or response to a friend's request, the particulars are not disclosed and the friendship is described in rather abstract and idealized terms.

20 In Memoirs of the Bloomsgrove Family, the series of letters takes place between two respectable, male American citizens, whereby the addressee of the exchange remains a conceptual gap to be filled by the reader. The fact that only one side of the exchange is given makes it easier for the reader to assume the role of the addressee as much as it underscores the one-directional didactic impetus of the work. The invocation of the friendly exchange in the first letter is prescriptive rather than descriptive:

I am honored, my dear sir, by the correspondence with which you favor me; and gratified, by the friendly manner in which you write to one, who can lay no other claim to your friendship, than that of benevolence. While your observations, on the principles of society and government, entertain, they improve the mind. There is a pleasure, in finding the sentiments of others agree with your own; and mutual advantage may arise, by an interchange of ideas, while glowing friendship becomes more ardent and more pure: there is a luxury in friendly intercourse, unknown to vulgar minds; nor can the vicious ever taste its purest delights. (13)

While the first two sentences suggest that the letters are taken out of an ongoing-equally entertaining and instructive-exchange on "the principles of society and government", the ensuing remarks on the virtues of friendship assume such a general tone that the reader may easily find himself addressed as the writer's respectable friend. Note, for instance, the impersonal pronominal value of "your" in "finding the sentiments of others agree with your own" or the potential modality in "mutual advantage may arise, by an 
interchange of ideas" (13). In fact and despite the labeling of the letters as "Domestic Memoirs" (n. pag.) in the title that precedes the first letter, the letters may be read as public letters addressed to all respectable citizens of Philadelphia, in which case the first sentence may be re-interpreted as a captatio benevolentiae that thanks the reader for having purchased the book. The communicative scenario in Hitchcock's works invokes what Michael Warner refers to as the "republican" readership. ${ }^{14}$ Reading is viewed as an act of public virtue and civic humanism. It projects a reader who transcends his corporeal and experiential self in the disembodied role of a citizen-critic.

If the sentimental epistolary novel is concerned with reflecting and communicating one's feelings in order to forge a link between feeling and reason, then Memoirs of the Bloomsgrove Family represents the reverse case. Feeling and emotional delight are the product of mutual agreement on reasonable ideas. The book engages or disengages with the issue of sensibility on a strictly didactic plane interspersed with a few stories on moral and immoral behavior.

In raising reflections on immediate experience and feelings to the theoretical level of projecting a national system of education, the novel's cardinal concern with the female character is reduced to the outlines of an example. Significantly, in the dedication of the novel, which is set in a prestigious calligraphic typeface, the author appeals to Mrs. Washington, as the primary and model character for female education: "It must add much to the happiness of your present situation, that your example, being more generally known, will have a more general influence in forming the female character" (iv).

Ironically, the forming or even framing of the female character resembles the framing of the very narrative content itself: both are reduced to the bottom level of the discourse. The fact that the narrative keyword "ANECDOTES" appears at the very end of the elaborate titular addendum is revealing in this respect. It is symptomatic of the lack of independence attributed to the narrative mode that the word "anecdotes" comes last. While the dedication requests the First Lady for patronage, she does not, like other good or bad examples of female characters, have a voice in the exchange; or she does only by implication-by giving permission to publish the dedicatory epistle. Thus the republican construction of a disembodied citizen-critic readership, which presents reading as a public act of exchanging virtuous ideas, has a striking correlation in the conception of narrativity. Although stories are invoked as means to represent vicissitudes of life, the experientiality and corporeality of the narrative content is at the same time abstracted and transcended by delimiting it to its exemplary function.

This communicative pattern of framing the epistolary novel (which may be paraphrased as "author = letter writer addresses unnamed recipient") reflects not only the republican paradigm of presenting fictional discourse with an aura of official public discourse, it is also representative of what can be described as a male framing strategy of early epistolary narratives in the US. It can be contrasted with a female framing strategy that evolves from a rhetoric of contiguity and aims at a non-transgressive protocol of mediating epistolary communication. I will discuss The Hapless Orphan (1793) and Ann Eliza Bleecker's The History of Maria Kittle (1797) as examples of this mode of epistolary framing of fiction. 


\section{Reframing Private Communication: the Subversion of the Epistolary Form}

According to this gendered dichotomy of epistolary schemes, William Hill Brown's The Power of Sympathy (1789), which is generally viewed as the first American novel and incidentally comes closest to the European model of epistolary fiction, can be described as a male model of epistolary fiction directed to a female audience. In contrast with the onedirectional correspondence in Memoirs of the Bloomsgrove Family, The Power of Sympathy consists of several strains of exchanges involving five characters. It presents, as announced in the dedication, four fatal stories of seduction. Yet, these stories are not enacted or dramatically presented. Told as warning examples to the young Harrington and Harriet, they constitute mere subplots of the novel.

Again the subduing of the narrative embodiment shows how novelists and publishers were often at pains to reconcile demands for sensational and presumably true-to-life fictions without facing reproaches of immorality. As Cathy Davidson (90ff) has pointed out, the promise of an infamous and true story about "the fatal Consequences of Seduction" (Brown 5) is highlighted by the frontispiece, which depicts a woman who has just poisoned herself. Yet, the sensational lure is only partially warranted by the main text, for the theme of seduction largely persists in moralizing comments. The "Story of Ophelia", which the caption over the frontispiece announces, turns out to be only a marginal episode (recounted through letters XXI to XXIII).

The stories of seduction occur at a remove from the main story line to provide critical distance to "represent the specious causes, and to expose the fatal consequences of seduction" (Brown 5). To the same end, the novel creates a communal arena through the voices of Reverend Holmes, Mrs. Holmes and M. Worthy, who orchestrate the exchange of Harriet and Harrington with moralistic glossing and lengthy discourse on education and proper conduct. In fact, this staging of a "secondary" or "vicarious" public through a series of personal letters draws attention to the cultural tension of printing private and imaginative reading matter in a cultural context that identified print with the public. ${ }^{15}$

Brown makes little effort to intertextually align his novel with other non-fictional discourse types. Instead he resorts to what I have referred to as the second major strategy of presenting fiction in a favorable light. He defends his work from the Puritan critique of fiction by exempting it from other novels and romances, which-as the author concedeshave "not been received with universal approbation" (7). Notably, Brown cautiously avoids either generic mark for his own text but prefers to use the neutral term "letters".

Similarly, Eliza Bleecker's The History of Maria Kittle (1797) exploits the epistolary communicative design to exempt her narrative from the criticism leveled at fiction: "However fond of novels and romances you may be, the unfortunate adventures of one of my neighbours, who died yesterday, will make you despise that fiction, in which, knowing the subject to be fabulous, we can never be truly interested". Bleecker's argument parallels that of Brown's preface to The Power of Sympathy. The crucial difference lies in the stance from which it is voiced. While in The Power of Sympathy these claims are in ornately and elaborately designed paratexts, which may be attributed to either the author, editor, or publisher, Bleecker integrates them at the beginning of the novel into a personal address to her half-sister, which follows an unassuming title page (see figure 2). 
Modifying the epistolary scheme set up by Hitchcock and others, the communicative pattern in The History of Maria Kittle represents a characteristic female strategy of framing early epistolary fiction, in which the author and composer of letters addresses a specified recipient, here her half-sister Susan Ten Eyck. The novel deviates from the conventional epistolary form in another respect: it presents the story in one long letter. Although the recent death of Maria Kittle is mentioned at the very beginning as the immediate cause of the narration, the author does not take advantage of the temporal and perspective openness of the epistolary form. Instead of relating the events from different perspectives and different points in time, the story is recounted from a straightforward third-person perspective. The author does not present herself as an editor, but as an informed acquaintance: "While this lady was expiring, Mrs. C----- V-------, her near kinswoman, related to me her unhappy history, in which I shall now take the liberty of interesting your benevolent and feeling heart" (3).

Figure 2: Title page and beginning of Ann Eliza Bleecker, The History of Maria Kittle (1797)

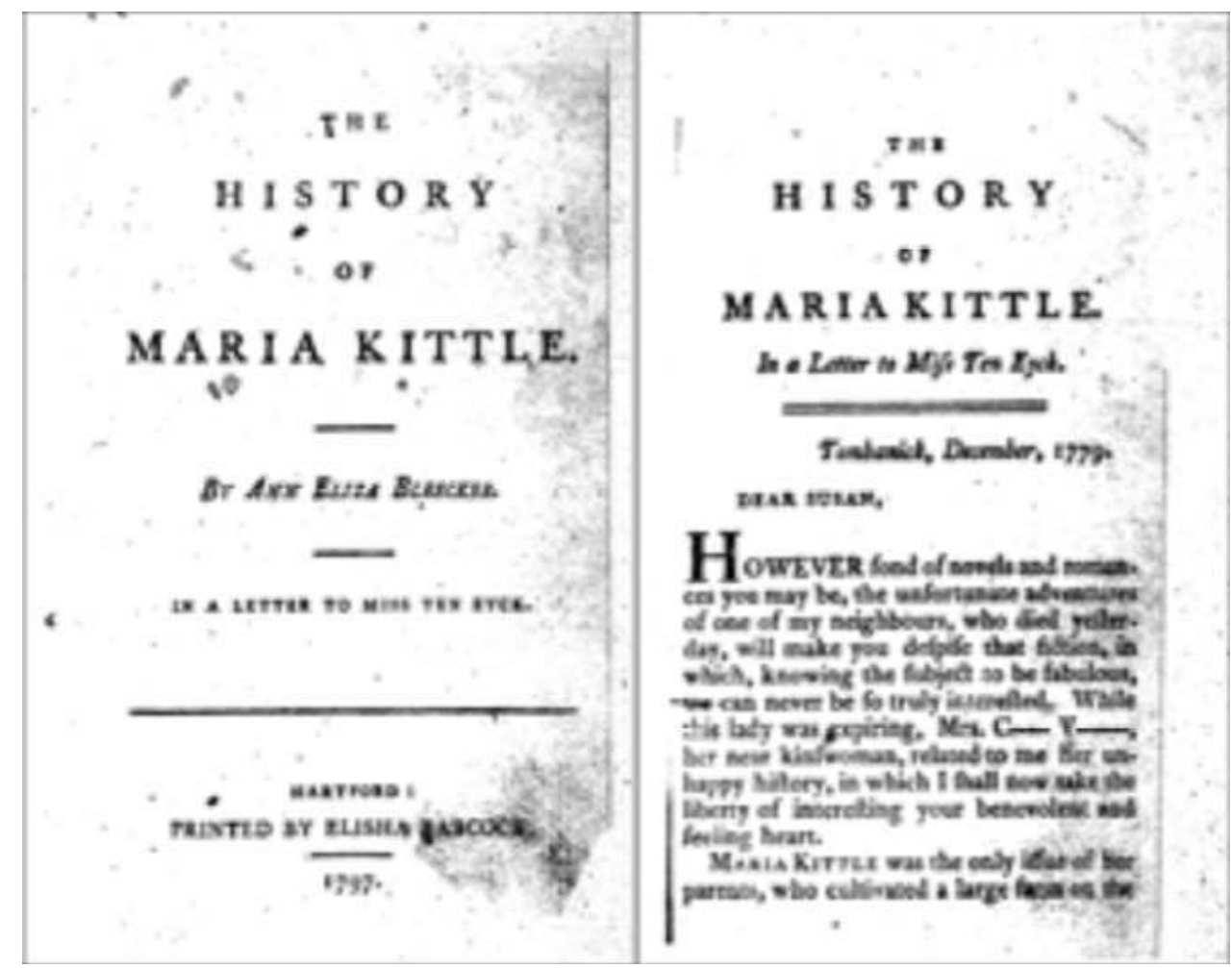

In contrast to Hitchcock's conceptual framing of the exchange by means of allegory, idealization, and abstraction, Bleecker's specific details about the time and place of a familial communicative situation are highly contiguous. Her appeal to the "benevolent and feeling heart" follows Warner's description of a sympathetic reading that characterizes the later "nationalist" paradigm of readership. The epistolary communication in Maria Kittle is a distinctly private yet allegedly factual one. In this sense the excessive markers of contiguity (such as the specification of sender and recipient, the vouchsafing of the story's truthfulness through personal acquaintance, recentness as well as the familial context of communication) compensate for the lack of authority that imbues public discourse. 

(1793) the private dimension of the novelistic communicative situation is underscored by framing the epistolary novel within another epistolary exchange. In an "Introductory Letter" Maria B. responds to her sister's request by sending the letters she has received from the eponymous heroine Caroline Francis together with her brother's account on the latter's unfortunate death. The twofold epistolary embedding amplifies the paratextual claim that the novel is "founded on incidents in real life" (qtd. from title page) as much as it avoids the dilemma of betraying the privacy of personal correspondence. As Perry remarks, "[r]eading the letters written and intended for other eyes is the most reprehensible invasion of privacy and consciousness in epistolary fiction. There are overtones of sexual invasion [...] in the intercepting or 'violating' of another's words" (130). In The Hapless Orphan the transgression involved in publishing a private correspondence is at least partially contained by embedding the exchange within the epistolary communication among family members. Thus the editorial arrangement of the book is conspicuously muted or relegated to the publisher, whose air of public authority is made present in the variegated typographic layout and ornate emblems, which during the early stage of American novel-publishing were typical of non-fictional book design (see figure 3). Significantly, Maria B., who performs the task of the fictive editor, poses not only as first reader, as is commonly the case with fictive editors in epistolary novels, she is at the same time the originally intended receiver of the letters. 
Figure 3: Title page and beginning of The Hapless Orphan (1793)

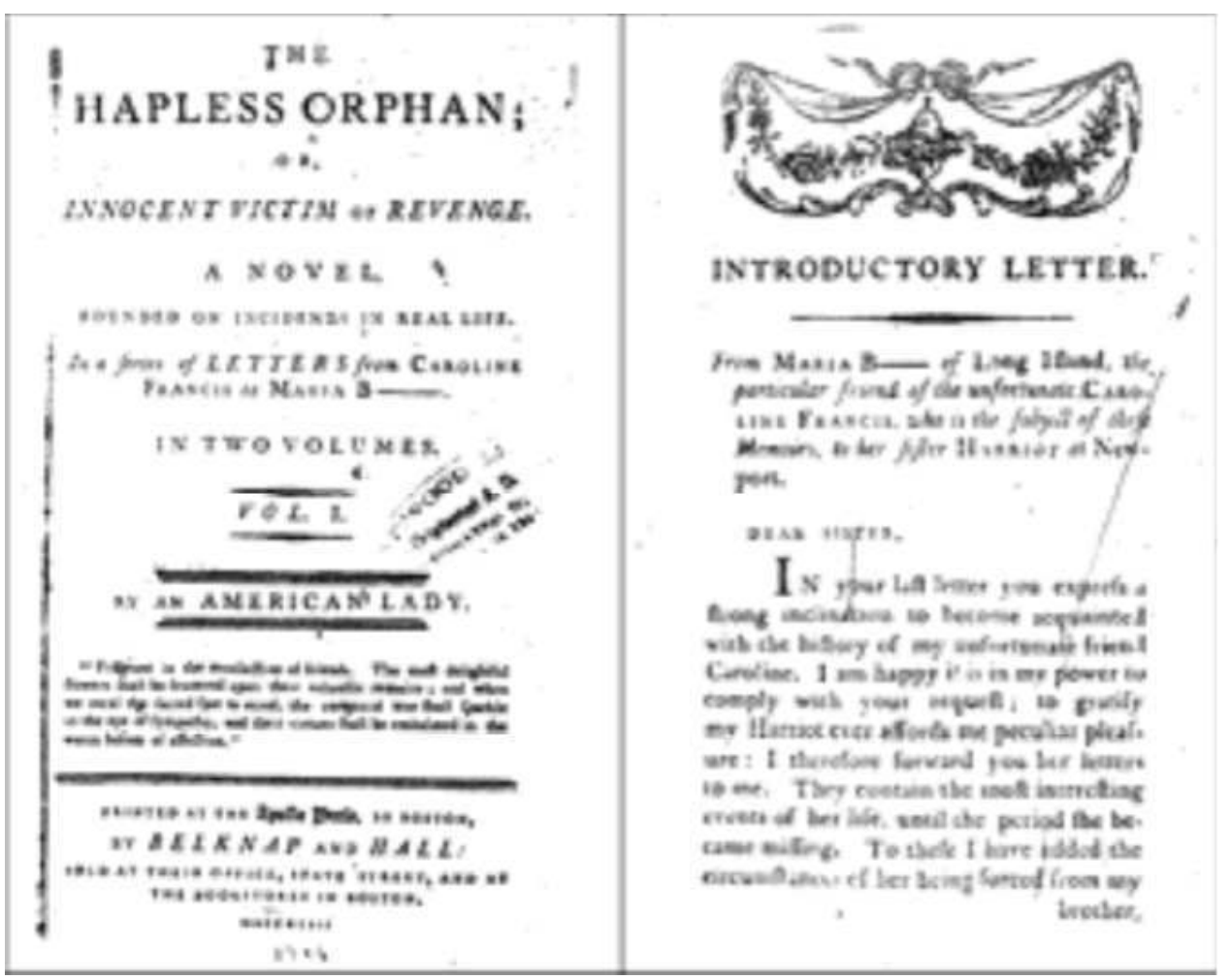

Her close relation to the novel's main protagonist further allows her to draw on other non-documentary sources such as her brother's knowledge about Caroline Francis' mysterious death. This has the advantage that the "morally questionable" circumstances that led to the disappearance of the heroine can be reported in third person perspective (instead of being presented by the heroine herself) and are thereby subjected to Maria's narrative control, who assumes a guardian role in the exchange with her sister. Thus, similar to Bleecker's The History of Maria Kittle, the epistolary framing in The Hapless Orphan is exploited to highlight the redemptive community women could share in the act of telling stories through postal communication.

\section{The End of Epistolarity}

The examples of epistolary fiction discussed above reveal that in the United States the subduing of overt authorial control, which is typical of epistolary fiction, was met with considerable resistance. In the case of The Power of Sympathy the narrative action is relegated to the level of subplots and footnotes, and excessively framed by moral reflections and didactic discourse. Another effective strategy in dealing with this problem was to align the author's extra-fictional stance with that of the (innerfictional) correspondent. Yet another way was to limit the epistolary frame to the outer communicative dimension, as is the case in Bleecker's The History of Maria Kittle, which subverts the novel's epistolary design by finishing the heroine's life-story in authorial third-person perspective. Similarly, in The Hapless Orphan, the limited perspective of the heroine's epistolary testimonies are ultimately contained in the extradiegetic sender's account of the fate of Caroline Francis. In a sense the last model points to the further 
historical development of the sentimental novel in the United States: namely the return to third-person narration. In "Charlotte Temple and the End of Epistolarity", Blythe Forcey even argues that, because of its lack of unifying authorial "narrative guidance, the epistolary novel could not make the successful crossing to the New World" (228). The single-letter epistolary form proved to be very influential for another novelistic genre. Many of Charles Brockden Brown's gothic novels are composed in one or very few letters. His novels, which are often referred to as performances, represent an interesting innovation in mediating the story. In Edgar Huntly; or, Memoirs of a Sleep-walker (1799) the notion of performance appears both in paratexts (in a note "To the Public") as well as in intratextual framings like the metanarrative beginning of the "memoirist" Edgar Huntly:

I sit down, my friend, to comply with thy request. At length does the impetuosity of my fears, the transports of my wonder, permit me to recollect my promise and perform it. At length am I somewhat delivered from suspense and tremors. At length the drama is brought to an imperfect close, and the series of events that absorbed my faculties, that hurried away my attention, has terminated in repose.

Till now, to hold a steadfast pen was impossible [...] (4)

Brown frames his novels as scientific illustrations proving "known principles of human nature" (Wieland, "Advertisement"). However, the fiction marker "performance" suggests a rather distinct separation between an external situation of reception and an internal dramatic situation. While he purportedly sets up his novels within the scientific discourse of rationality, the sense of autonomy that his 'narrative illustration' attains in fact defies the purported enlightening claim of scientific rationality. By creating a fullblown internal speech situation as a performance in its own right, Brown sets up a dramatic stage that is congenial to his highly unreliable narrators. In this respect, Brown's novels can be considered a daring literary experiment that is directed at the anxiety of its culture to control the reader's imagination.

\section{BIBLIOGRAPHY}

BAYM, Nina. “The Romantic Malgré Lui: Hawthorne in the “The Custom House.” ESQ: A Journal of the American Renaissance 19 (1973): 14-25.

BAYM, Nina. The Scarlet Letter: A Reading. Boston: Twayne, 1986.

BATESON, Gregory. Steps to an Ecology of Mind; Collected Essays in Anthropology, Psychiatry, Evolution, and Epistemology. San Francisco: Chandler, 1955/2000.

BeLKNAP, Jeremy. The Foresters, an American Tale. Boston: Thomas \& Andrews, 1792.

BLEECKER, Ann Eliza. History of Maria Kittle. Hartfort: Babcock, 1797.

BRown, Charles Brockden. Wieland; or, the Transformation. An American Tale. New York: T. \& J.

Swords for Hocquet Caritat, 1798.

BRown, Charles Brockden. Edgar Huntly; or, Memoirs of a Sleep-Walker. Philadelphia: Maxwell, 1799. 
BRown, William Hill. The Power of Sympathy (1789). In The Power of Sympathy and The Coquette. Ed. Carla Mulford. New York: Penguin, 1996. 1-103.

BRown, William Hill. Ira and Isabella; or, the Natural Children. A Novel, Founded on Fiction. Boston: Belcher and Armstrong, 1807.

CоOK, Elizabeth Heckendorn. Epistolary Bodies: Gender and Genre in the Eighteenth-Century Republic of Letters. Stanford: Stanford UP, 1996.

DAvidson, Cathy N. Revolution and the Word: The Rise of the Novel in America. New York: Oxford UP, 1986.

DAVIS, Lennard J. Factual Fictions: The Origins of the English Novel. New York: Columbia UP, 1983.

ELLIS, Markman. The Politics of Sensibility: Race, Gender and Commerce in the Sentimental Novel.

Cambridge: CUP, 1996.

FoRCEY, Blythe. "Charlotte Temple and the End of Epistolarity". American Literature 63.2 (1991): $225-41$.

FOSTER, Hannah Webster. The Coquette: Or, the History of Eliza Wharton. Boston: Samuel Etheridge for E. Larkin, 1797.

GenETtE, Gérard. Seuils. Paris : Éditions du Seuil, 1987.

GILMORE, William J. Reading Becomes a Necessity of Life: Material and Cultural Life in Rural New England, 1780-1835. Knoxville: University of Tennessee P., 1989.

GoffMAN, Erving. Frame Analysis: An Essay on the Organization of Experience. Cambridge: Harvard UP, 1974.

The Hapless Orphan; or, Innocent Victim of Revenge. Boston: Belknap \& Hall, 1793.

HAWTHORNE, Nathaniel. The Scarlet Letter. Boston: Ticknor, Reed, and Fields, 1850.

Нiтснсоск, Enos. Memoirs of the Bloomsgroove Family. Boston: Thomas \& Andrews, 1790.

Hiтснсоск, Enos. The Farmer's Friend, or the History of M. Charles Worthy. Boston: Thomas \& Andrews, 1793.

HowE, Daniel Ward. Making the American Self: Jonathan Edwards to Abraham Lincoln. Cambridge: Harvard UP, 1997.

LANSER, Susan Sniader. The Narrative Act: Point of View in Prose Fiction. Princeton: Princeton UP, 1981.

MCKeon, Michael. The Origins of the English Novel, 1600-1740. Baltimore: Johns Hopkins UP, 2002. MonTANDON, Alain. «Un espace pour soi : solitude et écriture épistolaire ». Solitudes : Écriture et Représentation. Ed. André Siganos. Grenoble : Grenoble Publication, 1995, 161-170.

PeArson, John H. “The Politics of Framing in the Late 19th Century”. Mosaic 23 (1990): 15-30.

PICARD, Hans Rudolf. Die Illusion Der Wirklichkeit Im Briefroman Des Achtzehnten Jahrhunderts.

Heidelberg: C. Winter, 1971.

QUENDLER, Christian. "Veil, Curtain, Picture, Screen: A Reading of Initial Framings in NineteenthCentury American Fiction”. AAA - Arbeiten aus Anglistik und Amerikanistik 29.2 (2004): 217-237.

QUENDLER, Christian. "Frame Analysis and Its Contribution to a Historical and Cultural Theory of Literary Fiction: A Comparison of Initial Framings in James Fenimore Cooper's the Spy and 
Gertrude Stein's The Making of Americans". Framing Borders in Literature and Other Media. Ed. Walter \& Werner Wolf Bernhart. Amsterdam: Rodopi, 2006. 229-262.

TENNEY, Tabitha. Female Quixotism: Exhibited in the Romantic Opinions and Extravagant Adventures of Dorcasian Sheldon. Boston: Thomas \& Andrews, 1801.

ToRgovnick, Marianna. Closure in the Novel. Princeton: Princeton UP, 1981.

The Vain Cottager: Or, the History of Lucy Franklin. New Haven: Sidney's Press for Cocke, 1807.

WARNER, Michael. The Letters of the Republic: Publication and Public Sphere in Eighteenth-Century America. Cambridge: Harvard UP, 1990.

WoLf, Werner. "Framing Fiction: Reflections on a Narratological Concept and an Example: Bradbury, Mesonge". Grenzüberschreitungen: Narratologie im Kontext / Transcending Boundaries: Narratology in Context. Ed. Walter Grünzweig \& Andreas Solbach. Tübingen: Narr, 1999, 97-146.

\section{NOTES}

1. See also Mark G. Vásquez, Authority and Reform, esp. 20-29.

2. See esp. 187.

3. Another important early contribution to a literary theory of framings contains Susan Sniader Lanser's, The Narrative Act: Point of View in Prose Fiction.

4. For a systematic typology of literary framings see Werner Wolf, "Framing Fiction: Reflections on a Narratological Concept and an Example: Bradbury, Mesonge".

5. For a more detailed discussion of these dimensions of twofold structure of novels see Christian Quendler, "Frame Analysis and its Contribution to a Historical and Cultural Theory of Literary Fiction".

6. See Howe, Making the American Self, 7.

7. For a historical theory of sensibility and its cultural practice in the sentimental novel see Markman Ellis, The Politics of Sensibility, 5-49.

8. These features are based on Hans Rudolf Picard's discussion of aesthetic illusion in epistolary fiction Die Illusion der Wirklichkeit im Briefroman des achtzehnten Jahrhunderts.

9. The findings of this essay are based on a sample analysis of some five hundred novels published between 1790 and 1900. See also G. Harrison Orians, "Censure of Ficton in American Romances and Magazines".

10. Both the Power of Sympathy and The Coquette draw on local scandals, a practice for which authors often earned the rebuke of the parties involved. An-albeit ironic-predecessor of the legal framing conventions to disclaim intentional resemblances to living persons can be found in William Hill Brown's posthumously published novel Ira and Isabella; or, The Natural Children (1807), which declared on the title page that is was "A Novel, Founded on Fiction".

11. See also Nina Baym, "The Romantic Malgré Lui: Hawthorne in the 'The Custom House" and The Scarlet Letter: A Reading; Marianna Torgovnick, Closure in the Novel; John H. Pearson, "The Politics of Framing in the Late 19th Century"; Quendler, "Veil, Curtain, Picture, Screen."

12. On the interdiscursive origins of the novel see also Lennard J. Davis, Factual Fictions and Michael McKeon, The Origins of the English Novel.

13. The dedication also provides an explicit statement of the novel's edifying rationale and the importance of the exemplar: "The following sheets, furnished with the Materials from the private Character of one who does honor to his Occupation, while it affords an Example of those Virtues wherein their true Dignity principally consisteth, and written with a special View to their Entertainment and Improvement, are Respectfully Inscribed by the Author" (n. pag.). 
14. See Warner, The Letters of the Republic, ch. 5.

15. Ibid., 120.

16. See also Alain Montandon, « Un espace pour soi : solitude et écriture épistolaire », 161-170.

INDEX

oeuvrecitee Edgar Huntly, Farmer's Friend (The), Foresters (The), Hapless Orphan (The), History of Maria Kittle (The), Ira and Isabella, Coquette (The), Memoirs of the Bloomsgroove Family, Power of Sympathy (The), Scarlet Letter (The), Vain Cottager (The), Wieland 